\title{
„Megfogyva bár, de törve nem..." avagy az ADF túlélésének és megújulásának dinamikája
}

\begin{abstract}
A Szövetséges Demokratikus Erök, vagyis az ADF egy közép-afrikai dzsihádista szervezet, amely jelenleg a Kongói Demokratikus Köztársaság keleti részén, ÉszakKivuban tevékenykedik. A szervezet eredete Uganda nyugati részére vezet vissza, ahol az ADF a Museveni-rezsim számára egyre nagyobb fenyegetést jelentett, így végül az ugandai hadsereg kiüzte őket. A felkelőszervezet 25 éves fennállása alatt a megújulás és alkalmazkodás módszerét magas szintre fejlesztette, amire az őt ért sorozatos támadások miatt szüksége is volt. Az Iszlám Állammal való kapcsolata pedig új perspektívába helyezheti az ADF megitélését, egyre nagyobb biztonságpolitikai kockázatot tulajdonitva neki.
\end{abstract}

Kulcsszavak: ADF, Kongói Demokratikus Köztársaság, dzsihádizmus, Iszlám Állam, ISCAP

\section{"Though depleted, but not broken..." or the Dynamics of ADF Survival and Renewal}

The Allied Democratic Forces, or ADF, is a Central African jihadist organisation currently operating in North Kivu, in the eastern part of the Democratic Republic of Congo. The origins of the organisation go back to western Uganda, where the ADF posed a growing threat to the Museveni regime, so they were eventually expelled by the Ugandan army. During its 25-year existence, the insurgent organisation developed the method of renewal and adaptation to a high level, which it also needed because of the series of attacks it had received. And its relationship with the Islamic State could put the ADF's perception in a new perspective, attributing increasing security policy risks to it.

Keywords: ADF, Democratic Republic of the Congo, jihadism, ISIS, ISCAP

\section{Bevezetés}

A Kongói Demokratikus Köztársaság (KDK) és Uganda határvidéke az elmúlt évtizedekben egy puskaporos hordóvá vált. Olyan térség ez, ahol az állami jelenlét hiánya valósul meg, és alapvetően instabilitás jellemző. A határok egyszerre korlátoznak és biztosítanak átjárhatóságot. Mivel perifériáról van szó, így a nemzeti identitás gyenge. Sokkal inkább dominál az etnikai hovatartozás, ami gyakran konfliktusok kiindulópontjaként szolgálhat. Egy ilyen politikailag, gazdaságilag és katonailag perifériális terület magában hordoz-

Pintér Tibor a Szegedi Tudományegyetem Állam és Jogtudományi Kar Nemzetközi és Regionális Tanulmányok Intézetének PhD-hallgatója. E-mail: teibor93@gmail.com 
za az erőszak továbbterjedésének lehetőségét egyik államból a másikba. ${ }^{2}$ Ebből következik az, hogy számos felkelőszervezet fordul és fordult meg a térségben, így vált a határvidék egyre fontosabb stratégiai tereppé biztonságpolitikai szempontból. A KDK-ban ezt a jelenséget fokozza az, hogy a Rwenzori-hegység vidéke alkalmas a gerilla harcmodor alkalmazására, komoly veszteséget okozva a reguláris haderőknek.

Ezek közül az egyik, az elemzésben vizsgált Szövetséges Demokratikus Erök (ADF - Allied Democratic Forces). Az ADF-nek a maga 25 évével a dzsihádista szervezetek történetében komoly múltja van. Ez idő alatt komoly nyomás alá helyezték és helyezik a térség reguláris haderői. A csoport többször komoly válságba süllyedt, de nem szűnt meg, ami talán két kulcsszónak köszönhető: megújulás és alkalmazkodás. A következőkben az ADF történetét e két fogalom gyakorlati alkalmazása segítségével vizsgálom meg kronologikusan. Felépítésében az elemzés első harmada az ADF-NALU létrejöttét, valamint utóbbi kiválását mutatja be, majd folytatódik a középső, átmeneti időszakkal, végül az újjáalakult és belső átszervezésen átesett, nemzetközi szinten egyre veszélyesebbé váló szervezet bemutatásával zárul, kiegészítve az Iszlám Állammal való kapcsolatát. Szeretném hangsúlyozni, hogy bár csak néhány felkelésellenes műveletet veszek górcső alá, ez nem jelenti azt, hogy ne történtek volna kisebb volumenü összecsapások, támadások, amelyek a szinte folyamatos nyomást eredményezik. Ezt a folyamatot még érdekesebbé teszi az, hogy hogyan tudott megerösödni egy ugandai dzsihádista szervezet a KDK-ban, egy olyan országban, ahol a lakosság mindössze $1,3 \%$-a $\mathrm{a}^{3}$ muszlim vallású.

Még a bevezető részben tisztázni szeretném, hogy az ADF terrorista- vagy felkelöszervezet. Hiszen az Amerikai Egyesült Államok szerint terrorszervezet, mivel az Iszlám Államnak esküdött hűséget. Habár él a terrorral mint eszközzel, mégis a NATO meghatározása ${ }^{4}$ alapján felkelöszervezetnek titulálom a következőkben, alátámasztva a definícióban meghatározott elemeket.

\section{A két szervezet története}

A mai ADF kialakulása két szervezet egyesülésére vezethető vissza, amelyek közül az első az Ugandai Nemzeti Felszabadítási Hadsereg (NALU - National Army for the Liberation of Uganda). A bakonzo és bamba nép az ugandai-kongói határvidéken él, és szoros kulturális, gazdasági és kereskedelmi kapcsolatban áll egymással. A gyarmati időszakban a britek közvetett uralma idején alárendelt szerepbe kerültek. A dekolonizációs folyamatok után sem történt változás, földrajzi elhelyezkedésük miatt továbbra is marginalizáltak maradtak, mivel a határvidéken helyezkedtek el. Az elégedetlenség odáig vezetett, hogy létrejött

\footnotetext{
Lindsay Scorgie: Peripheral Pariah or Regional Rebel? The Allied Democratic Forces in the Uganda / Congo Borderland. The Commonwealth Journal of International Affairs, 100. (2011), 412. 3-7. [online], 2011. 02. 18. Forrás: static1. squarespace.com [2021. 06. 17.]

Democratic Republic of the Congo. [online], 2021. 06. 14. Forrás: cia.gov [2020. 06. 15.]

Felkelőszervezet: olyan szervezett, gyakran ideológiailag motivált csoport vagy mozgalom, amely politikai változásokat akar végrehajtani vagy megakadályozni, vagy egy országon, régión belül kormányzó hatalmat megdönteni, a lakosság erőszakkal és felforgatással történő meggyőzésére vagy kényszerítésére összpontosítva. Lásd NATO: NATO Standard, Allied Joint Doctrine For Counter-Insurgency (COIN). 29. [online], 2016. 07. Forrás: publishing.service.gov. uk [2021.09.30.]
} 
a Rwenzururu Mozgalom az itt élő bakonzo-bamba nép körében, amely egy paraszti gerillamozgalomnak tekinthetö. A mozgalom célja a politikai autonómia kiharcolása volt egy királyság létrehozása révén, különálló irányító testülettel, elszakadva Ugandától. ${ }^{5}$ Erre történt is kísérlet a Rwenzururu Királyság megalapításával, de az ugandai hadsereg ezt csírájában elfojtotta, arra kényszerítve a mozgalom harcosait, hogy a szomszédos Kongóba meneküljenek. ${ }^{6}$ A mozgalom a Rwenzori-hegység kongói oldalán vetette meg a lábát, továbbra is fenyegetést jelentve Kampala számára. Ezen a határvidéken a harcosok támogatottsága egyre inkább nőtt, leginkább az egy királyságban történő nemzetegységesítés célja miatt. ${ }^{7}$

A fordulat 1982-ben következett be, amikor Milton Obote ugandai kormányához a bakonzói Charles Wesley Irema-Ngoma csatlakozott, és ellátta Kasese körzet közigazgatásának vezetését. ${ }^{8}$ Ennek következtében Obote autonómiát adott a Rwenzururu Királyságnak, ami a mozgalom tagjaival szembeni amnesztiával párosult. Ezzel sokan éltek, így a mozgalom gyengülni kezdett. ${ }^{9}$ 1986-ban azonban az ugandai politikában hatalmas változás következett be: Obote megbukott, és Yoweri Museveni került a helyére, aki elhanyagolta a régiót és ellehetetlenítette a Rwenzururu Királyság müködését. A Rwenzururu Mozgalom megmaradt radikális tagjaival együtt Amon Bazira ${ }^{10}$ létrehozta a NALU-t, amit a KDK (akkori nevén Zaire) támogatott. Museveni számára a szervezet megalakulása egyre nagyobb kockázatot jelentett, így 1988-ra az ugandai hadsereg révén végérvényesen kiűzte az országból, vissza a Rwenzori-hegységbe. Így a NALU kongói-ugandai mozgalommá vált, mivel egy kongói bázisterülettel, ám ugandai vezetéssel rendelkeztek. ${ }^{11}$ Innentől kezdve Mobutu Sese Seko KDK-ja, Daniel Arap Moi Kenyája és az 1990-es évek elejétől Omar al-Bashir Szudánja támogatta a szervezetet, mivel ezen államok célja a Museveni-rezsim működésének aláásása volt. A NALU ehhez tökéletes eszköznek tünt, bár az Ugandába való betöréseik nem bizonyultak kellően eredményesnek. $^{12}$

A NALU mellett a másik szervezet az ADF, amelynek a létrejötte az ugandai rezsimváltásra vezethető vissza. Museveni hatalomra kerülése után az egyik legfontosabb céljává a muszlim erők kézben tartása vált. Ennek kapcsán a legnagyobb problémát a Tablighmozgalom jelentette számára, amelynek klerikusai szaúd-arábiai iskolákban tanultak. Ennek köszönhetően a Tabligh-mozgalom - erős szaúdi szalafista hatásra - az iszlám fundamentalista irányzatait hirdette, megkérdőjelezve az ugandai muszlim tudósok értelmezéseit. ${ }^{13}$ Bár a mozgalom a szalafista irányzatot képviseli, ellenzi az erőszakos

Kristof Titeca - Daniel Fahey: The many faces of a rebel group. The Allied Democratic Forces in the Democratic Republic of Congo. 5-7. [online] 2016. 09. Forrás: researchgate.net [2021. 06. 15.]

6 International Crisis Group: Eastern Congo: The ADF-NALU's Lost Rebellion. 2. [online], 2012. 12. 19. Forrás: crisisgroup.org [2021. 06. 12.]

Scorgie (2011) i. m. 7-8.

International Crisis Group (2012) i. m. 2.

Stig Jarle Hansen: Horn, Sahel and rift. Fault-lines of the African jihad. London, Hurst, 2019. 128-130.

Bazira az 1986-ban a leváltott rezsim hírszerző szolgálatainak vezetője volt.

1 International Crisis Group (2012) i. m. 3; Kristof Titeca - Kloen Vlassenroot: Rebels without borders in the Rwenzori borderland? A biography of the Allied Democratic Forces. Journal of Eastern Africa Studies, 6. (2012), 1. 6-7.

12 Hansen (2019a) i. m. 128-130.

13 Titeca-Fahey (2016) i. m. 5. 
dzsihádot. ${ }^{14}$ Museveni a mozgalom kordában tartására létrehozta az Ugandai Muszlim Legfelsőbb Tanácsot (UMSC - Uganda Muslim Supreme Council), amelyen keresztül egységbe szervezte a muszlim szervezeteket. Azonban az UMSC vezetésében a kormányhoz hü emberek kerültek túlsúlyba. Emiatt a Tabligh-mozgalom egyre inkább az intézményrendszer ellen fordult, és ennek hangot is adott. Ez a szembenállás 1991-ben csúcsosodott ki, amikor a mozgalom helyettes vezetője, egy bizonyos Jamil Mukulu fegyveres támadást indított az UMSC központja ellen. ${ }^{15} \mathrm{Az}$ incidens során négy rendőr meghalt, ${ }^{16}$ a kormány pedig körülbelül 400 Tabligh-tagot börtönzött be a magas-rangú vezetőkkel, többek között Mukuluval együtt. Ök 1993-ban szabadultak, és először megalapították a Szalafista Alapítványt (SF - Salafi Foundation), később pedig annak fegyveres szárnyát, az Ugandai Muszlim Szabadságharcosok Csoportját (UMFF - Uganda Muslim Freedom Fighters). ${ }^{17}$ Eleinte Uganda nem lépett fel erőszakosan e szervezetekkel szemben, de azzal, hogy kiképzőtábort létesítettek, a fegyveres szárny pedig Uganda riválisától, Szudántól kapott támogatást, Kampala akcióba lendült, és megsemmisítette a kiképzőtábort, majd 1995-re az UMFF-et végérvényesen kiűzték Ugandából. ${ }^{18}$

\section{Az ADF-NALU létrejötte}

1995-re így két Museveni-ellenes tömörülés telepedett le a KDK-ban: a NALU és az 1995-ben az átszökött UMFF-harcosokból létrejövő ADF. Utóbbi vezetője Abdallah Yusuf Kabanda volt, egyik helyettese pedig Jamil Mukulu. ${ }^{19}$ 1995-ben a két ideológiailag különböző szervezet Mobutu és Omar al-Bashir rezsimjei közbenjárásával egy új szervezetté olvadt össze ADF-NALU néven. ${ }^{20}$ Mobutu számára ez az új lázadó mozgalom ellensúlyozta a KDK keleti részén fekvő hutu milíciák elleni növekvő ugandai-ruandai együttmüködést. ${ }^{21}$ Mobutu biztosította a helyet és a legitimációt, mivel elismerte a szervezetet mint biztonsági szereplőt Kelet-Kongóban. Ennek köszönhetően a NALU-ADF a kongói kormány támogatásával toborzott, illetve a helyi vállalkozások együttmüködtek vele. Mindezek azt eredményezték, hogy 1996-ra a csoport 4000-5000 harcost számlált, akiknek a kiképzéséről Szudán gondoskodott. A harcosok 1996-ban például három hónapos kiképzést kaptak Kartúmban. A két ország olyan ütőképes szervezetet akart létrehozni, amely rajtaütései révén képes hatékonyan aláásni Uganda biztonságát. ${ }^{22} \mathrm{Az}$ évtized végére Nyugat-Ugandában megszaporodott a rajtaütések száma: 1998-ban két iskolát támadtak meg, ahol legalább 80 diák esett áldozatul gyújtogatás következtében, és több

14 Congo Research Group: Inside the ADF Rebellion - A Glimpse into the Life and Operations of a Secretive Jihadi Armed Group. 5. [online], 2018. 11. Forrás: congoresearchgroup.org [2021. 06. 14.]

15 Hansen (2019a) i. m. 130-131.

16 International Crisis Group (2012) i. m. 4.

17 Titeca-Fahey (2016) i. m. 5.

18 International Crisis Group (2012) i. m. 4.

19 Hansen (2019a) i. m. 132.

20 Stig Jarle Hansen: Tracking the DRC's Allied Democratic Forces and its links to ISIS. [online], 2019. 05. 08. Forrás: theconversation.com [2021. 06. 12.]

21 Titeca-Vlassenroot (2012) i. m. 8.

22 International Crisis Group (2012) i. m. 4-5. 
tucatnyit elraboltak. ${ }^{23} 1999$-re a támadások sorozatossá váltak, nem kímélve a civil lakosságot, mivel a megfélemlítés eszközével kényszerítették őket az együttmüködésre az akcióik végrehajtása során. ${ }^{24}$

Érdemes megvizsgálni a területet, ahol az ADF-NALU elkezdte kiépíteni bázisát, ahonnan támadásokat indított. A KDK keleti része (Észak-Kivu) egy klasszikus értelemben vett határvidéknek tekinthetö: egy hegyvidékes, sürü növényzetü, nehezen megközelíthető terület, és emiatt egy önálló gazdasági térségnek tekinthető a maga kereskedelmi útvonalaival és a természeti erőforrások csempészhálózataival. ${ }^{25}$ Emellett megfigyelhető az állami jelenlét hiánya. $\mathrm{E}$ hatalmi vákuumot az ADF-NALU igyekezett betölteni. A szervezet képes volt a térség vérkeringésének a részévé válni és jövedelmező gazdasági tevékenységeket kialakítani. Idővel a helyismeret is egyre meghatározóbbá vált. Számos felkelöcsoport működik a térségben, és a helyi társadalom összetétele is vegyes, amit az ADF-NALU felhasznált arra, hogy egy olyan transznacionális szövetséget alakítson ki, amely a gazdasági önfenntartás mellett segített számára a túlélésben és a támadások kivitelezésében. ${ }^{26}$

A rajtaütésekkel párhuzamosan két esemény együttes következményeként a szervezet életében fordulat következett be. Az első kongói háborúban Mobutu megbukott és Laurent-Désiré Kabila vette át a helyét Kongóban, aki már Museveni támogatását élvezte. Így az ADF-NALU számára a kongói rezsim is ellenséggé vált. ${ }^{27} \mathrm{Az}$ International Crisis Group tanulmánya szerint ekkor, vagyis 1997-2000 között a szervezet ugandai behatolásai következtében legalább 1000 ember meghalt, 150 ezer fó pedig elhagyni kényszerült lakóhelyét. Ez oda vezetett, hogy 1999-ben az ugandai hadsereg egy átfogó hadmüveletet indított Mountain Sweep néven, amelynek az volt a célja, hogy teljesen felszámolják a szervezetet. A művelet eredményeként számos harcost és parancsnokot sikerült elfogniuk. Viszont nem ez volt a legnagyobb csapás az ADF-NALU számára. Az ugandai hatóságok igyekeztek elzárni a szervezet pénzügyi csatornáit, ami két eseményben nyilvánult meg: bezáratták Ugandában a Greenland Bankot, amelynek állítólag kapcsolata volt a lázadókkal, illetve elzárták a szudáni logisztikai útvonalakat, ami szintén komoly következménnyel járt. ${ }^{28}$

Az utánpótlás drasztikus lecsökkentése és az ellenük irányuló offenzíva miatt a szervezetnek területileg, szerkezetileg és stratégiailag egyaránt változtatásokra volt szüksége. Kerülte a nyílt összecsapásokat és a Rwenzori-hegység sürü, kietlen területeire húzódott vissza. Ez hatékony védelmet nyújtott számára a reguláris erőkkel szemben. Ugyanakkor

\footnotetext{
23 T. Horváth Attila: Az ADF-NALU - Egy nagy múltú gerillaszervezet a Kongói Demokratikus Köztársaságban. In Afrikai terrorista- és szakadárszervezetek. Budapest, 2015. 439-455.

24 Titeca-Fahey (2016) i. m. 6-7.

25 Észak- és Dél-Kivu bányáiban jelentős mennyiségü ónérc, arany, valamint olyan fémek találhatók, amelyek a mobiltelefon-gyártáshoz elengedhetetlenek. Mindez a feketepiac alapja, olyan fegyverre és egyéb olyan eszközre cserélik, amelyek egy lázadó szervezet számára szükségesek. Lásd Besenyő János et al.: Országismertető - Kongói Demokratikus Köztársaság. Székesfehérvár, MH Összhaderőnemi Parancsnokság Tudományos Tanácsa, 2011. 38.

26 Scorgie (2011) i. m. 9-13.

27 Titeca-Fahey (2016) i. m. 11.

28 International Crisis Group (2012) i. m. 5-6.
} 
elvesztette bázisai és bevételi forrásai nagy részét. Teljes volt a káosz a szervezeten belül, és a kilátástalanság jelei mutatkoztak meg, amire jó példa, hogy 2000-ben tárgyalásba bocsátkoztak az ugandai kormánnyal, illetve 2001-ben Uganda amnesztiatörvényt fogadott el a fegyveres harcosokra vonatkozóan, amelyet a lázadók közül sokan ki is használtak. Mindez azt eredményezte, hogy a korábbi több ezres nagyságrendű harci állomány körülbelül száz före apadt. ${ }^{29} \mathrm{Az}$ ugandai beavatkozás mégsem tudta elérni az eredetileg kitüzött célt: nem sikerült teljesen felszámolni a szervezetet, és az ugandai katonák kivonulása után a Kongói Demokratikus Köztársaság Fegyveres Eröi (FARDC - Forces armées de la République démocratique du Congo) nem tudták megtartani a műveletben megszerzett pozíciókat. A nagyobb városok ellenőrzésére volt csak erejük, a vidéki területet és lakosságot magára hagyták. Az ADF-NALU kihasználta a lehetőséget és újra rátelepedett a vidékre, ${ }^{30}$ amelyet sikeresen ki tudott aknázni. Először jórészt a NALU kapcsolatait kihasználva igyekezett szívélyes viszonyt kialakítani, például a tagok helyi nőkkel kötöttek házasságot, és egyre szorosabban működtek együtt a helyi vezetőkkel az arany- és a fakereskedelemben. ${ }^{31}$ Ebben a periódusban az ugandai kormány megbuktatása helyett a cél a túlélés lett. Innentől kezdve egyre kevesebb információt osztott meg a csoport magáról a közvélemény számára, szigorúan ellenőrizték az erdei táboraik közötti mozgást, kevesen utazhattak a régión kívülre. Ennek a célja egyértelmüen a szervezetet célzó felderítés megnehezítése volt. ${ }^{32}$

\section{A NALU kiválása, az ADF átmeneti időszaka}

Az ADF-NALU-nak 2005-re a FARDC mellett az ENSZ Kongói Demokratikus Köztársaságbeli Stabilizációs Missziójának (MONUSCO - Mission de l'Organisation des Nations Unies pour la stabilisation en République démocratique du Congo) katonáival is szembe kellett néznie. Az általuk indított müveletek nem voltak eredményesek, viszont az ugandai kormány 2008-as bejelentése, hogy elismerik ${ }^{33}$ a Rwenzururu Királyságot, már annál inkább. Így az ADF-en belül a NALU-s múlttal rendelkezők az ENSZ DDRRR ${ }^{34}$ programjának keretében megadták magukat. Ekkorra az ADF már abszolút túlsúlyba került a szervezet vezetésében, a szövetség pedig tulajdonképpen megszünt, így innentől egyedül az ADF-röl beszélhetünk, amelynek a vezetője Jamil Mukulu lett. Arról sem szabad megfeledkezni, hogy ekkorra a szudáni támogatás teljesen megszünt, a csoport pedig

29 International Crisis Group (2012) i. m. 6.

30 Hansen (2019a) i. m. 135-136.

31 Congo Research Group (2018) i. m. 5.

32 Titeca-Fahey (2016) i. m. 7.

33 Az ugandai kabinet 2008. március 17-én kulturális intézményként ismerte el a Rwenzururu Királyságot, amely 2009-ben lett hivatalosan is elismerve. Lásd Rwenzururu Kingdom. [online], 2021. 06. 14. Forrás: fortuneofafrica.com [2021. 06. 14.]; No celebrations as Rwenzururu kingdom marks 11 years. [online], 2020. 10. 20. Forrás: independent. co.ug [2021. 06. 14.]

34 Az ENSZ lefegyverzési, leszerelési, hazatelepítési, újratelepítési és újrabeilleszkedési programja. (Disarmament, Demobilisation, Repatriation, Resettlement and Reintegration Programme.) 
önfenntartóvá vált. ${ }^{35} \mathrm{Ez}$ az életforma tulajdonképpen azt jelentette, hogy megadóztatták a helyieket, és ha a kongói hadsereg támadott, visszahúzódtak, elkerülve az ellenfél fó eröit, amint pedig a müvelet véget ért, az $\mathrm{ADF}$ a magukra hagyott helyiek körében tovább folytatta a befolyásának elmélyítését. A felkelőcsoport hasznot húzott a fakitermelésből, a kávé- és marihuána-termesztésből, valamint megadóztatta azokat az üzletembereket, akik védelmet kértek tőle. Söt az ADF zöldségeket és egyéb létfontosságú élelmiszereket termesztett, amiből jelentős részt biztosított támogatóinak. ${ }^{36}$ A nemzetközi szövetségesek hiánya, az újjászerveződés, a folyamatos nyomás és az új kihívások révén az ADF egyre szigorúbban ragaszkodott az iszlám törvényekhez, és a vallás egyre hangsúlyosabbá vált a szervezet mindennapi életében. ${ }^{37}$

A csoport nemzetközi ismertsége 2011-re megnőtt, amikor az ugandai kormány januárban hivatalosan is elfogatóparancsot adott ki Mukulu ellen, amit egy hónappal később az Interpol piros sarkos körözése ${ }^{38}$ követett. Becslések szerint ebben az időszakban körülbelül $420 \mathrm{~km}^{2}$ területet uraltak, és a fegyvereseik létszámát 1600-2500 före becsülték. ${ }^{39}$ Az ENSZ jelentése alapján az ADF egy államon belüli államot hozott létre, számos tábort müködtetett, amelyek tulajdonképpen falvak voltak úthálózattal összekötve. A madinai tábor volt a központ, ahol állítólag Jamil Mukulu is lakott. Saját bírósági rendszerrel, börtönnel és külön férfi-női iskolákkal rendelkezett. Utóbbinál nagy hangsúlyt fektettek az iszlám vallás oktatására és gyakorlására. ${ }^{40}$

\section{A teljes megújulás időszaka}

A 2010-es évek első felében a FARDC a MONUSCO-val karöltve egymás után három nagyszabású felkelésellenes műveletet indított az ADF ellen. Ezek közül a harmadik, a 2013 végén - 2014 elején elindított Sukola I. müvelet okozta a legnagyobb kárt az ADFnek. ${ }^{41}$ Több fronton haladva a hadsereg mélyen behatolt az ADF területére, és kiszorította a szervezetet számos táborából. A harcok során mindkét fél jelentős veszteségeket szenvedett el. Április elején, amikor a kongói hadsereg a szervezet központjához, a madinai táborhoz ért, az ADF két nagyobb csoportra vált szét. Az egyik csoportot Mukulu vezet-

\footnotetext{
International Crisis Group (2012) i. m. 10-11.

Hansen (2019a) i. m. 136-137.

Congo Research Group (2018) i. m. 6.

38 A vörös figyelmeztetés listájához azok tartoznak, akiket vádemelés vagy büntetés-végrehajtás miatt köröznek. A világ összes bünüldöző szervének megküldik a listát, hogy a rajta szereplő személyeket felkutassák, letartóztassák, és ha szükséges, kiadassák a megfelelő országnak ahhoz, hogy büntetőjogi eljárás alá vonják. Vö. View Red Notices. [online], 2021. 06. 16. Forrás: interpol.int [2021. 06. 16.]

39 Tara Candland et al.: The Islamic State In Congo. [online], 2021. 03. Forrás: gwu.edu [2021. 06. 12.]

40 United Nations Security Council: Letter dated 19 June 2014 from the Chair of the Security Council Committee established pursuant to resolution 1533 (2004) concerning the Democratic Republic of the Congo addressed to the President of the Security Council. 7-14. [online], 2014. 06. 25. Forrás: undocs.org [2021. 06. 13.]

${ }^{41}$ Congo Research Group (2018) i. m. 6.
} 
te, ${ }^{42}$ aki később elhagyta az országot, a másikat pedig Musa Baluku. ${ }^{43}$ Jól mutatja a káosz mértékét az, hogy a szétválás és a menekülés miatt az utánpótlási vonalak megszakadtak, továbbá nemcsak a kongói katonák okoztak komoly veszteséget, hanem az éhezés is. ${ }^{44}$ Az ENSZ becslései szerint a harcosok száma ekkor 100-300 före csappant. Az ADF belső válságát fokozta az, hogy Mukulut Tanzániában elfogták és letartóztatták, majd 2015 júliusában kiadták Ugandának. ${ }^{45}$

2015-re a Sukola I. müvelet megrekedt, és a FARDC képtelen volt tartani az állásait. $\mathrm{Az}$ ADF ezt kihasználta és elkezdte visszaszerezni az offenzíva előtti pozícióit. Ekkora viszont már egy új szervezet visszatéréséről beszélhetünk. ${ }^{46}$ Jamil Mukulu kísérletet tett ugyan a börtönből való vezetésre, de hamar bebizonyosodott, hogy ez hosszú távon nem lehetséges. Távollétében Musa Baluku, Mukulu másodparancsnoka és az ADF politikai biztosa lett a vezető, akinek már nem az volt a célja, hogy egy ugandai iszlám kormányt hozzon létre, hanem a szervezetet a szélesebb globális dzsihádista mozgalom részévé akarta tenni. ${ }^{47}$ Baluku az elődjével ellentétben a kezdetektől iszlám vallású volt, az pedig máig rejtély, hogy hogyan és pontosan mikor lett a csoport tagja, de az biztos, hogy azok között szerepelt, akik Ugandából a KDK-ba menekültek. A szervezeten belül ő képviselte a brutálisabb, szélsőségesebb álláspontot, amely miatt sokan dezertáltak. Ez megkönnyítette a hatalomátvételt, mivel így a szervezetben lévők többsége támogatta őt és a célját. ${ }^{48}$

Baluku vezetésével az ADF civilekkel való viszonya gyökeresen megváltozott. Mukulu törekedett a velük való jó kapcsolat kialakítására, egy szimbiózis fenntartására. Ehhez képest a Sukola I. művelet megkezdése után a szervezet harcosai megtorló hadjáratokba kezdtek, amelyek során atrocitások tömegét követték el a kongói lakossággal szemben. ${ }^{49} \mathrm{~A}$ megtorlások célja eredetileg azon személyek likvidálása volt, akik információval

42 A Mukulu-csoportba tartozók között volt Jamil Mukulu és családja, valamint Bisasso (pénzügyi főnök), Kikutte (hadseregparancsnok-helyettes), Magezi Abdul, Benjamin Kisokeranyo (Mukulu vezető tanácsadója) és számos más hoszszú ideje hivatalban lévő ADF-parancsnok, valamint számos olyan tag, akik az elit osztály részei. Körülbelül 30 föt tett ki a csoport létszáma. A menekülési útvonalukról keveset tudni, például azt sem, hogy mikor és pontosan hányan szöktek át közülük egy másik országba. Vö. United Nations Security Council: Letter dated 12 January 2015 from the Chair of the Security Council Committee established pursuant to resolution 1533 (2004) concerning the Democratic Republic of the Congo addressed to the President of the Security Council. 5-6. [online], 2015. 01. 12. Forrás: undocs.org [2021. 06. 13.]

43 Mukulu távozása után Musa Baluku elkezdte kiüríteni a központi (madinai) tábort. A nagyjából 1000-1200 emberrel Baluku a sürű erdőkbe vonult a kongói hadsereg elől. Számos ADF-vezető maradt itt: Hood Lukwago (hadseregparancsnok), Kalume (hadseregparancsnok-helyettes), Nasser (harci műveletek fönöke), Recoilance (belbiztonsági fönök), Muzzanganda (fegyverkovács), Adam (fegyverkovács segéd), Fezza (föparancsnok), Werason (kiképző oktató), Rafiki (kiképző oktató) és Mwanje (pénzügyi helyettes). Vö. United Nations Security Council: Letter dated 12 January 2015... i. m. 5-7.

44 United Nations Security Council: Letter dated 12 January 2015... i. m. 5-7.

45 United Nations Security Council: Letter dated 16 October 2015 from the Group of Experts extended pursuant to Security Council resolution 2198 (2015) addressed to the President of the Security Council. 5-7. [online], 2015. 11. 16. Forrás: undocs.org [2021. 06. 13.]

46 United Nations Security Council: Letter dated 16 October 2015... i. m. 5-7.

47 Candland et al. (2021) i. m. 17-18.

48 Candland et al. (2021) i. m. 35.

49 United Nations Joint Human Rights Office: Report on violations of human rights and international humanitarian law by the Allied Democratic Forces armed group and by members of the defense and security forces in Beni territory, North Kivu province and Irumu and Mambasa territories, Ituri province, between 1 January 2019 and 31 January 2020. 15. [online], 2020. 07. Forrás: ohchr.org [2021. 06. 13.] 
láthatták el a kongói hadsereget az ADF pozícióit, céljait és erejét illetően. A civilek elleni támadások alapvetően kisebb csoportokban zajlottak. A MONUSCO szerint 2014 októbere és 2015 júniusa között legalább 350 gyilkosság történt 50 különálló esemény során. Az áldozatok között nők és gyerekek is voltak. Többségében bozótvágóval támadtak, habár a szemtanúk szerint lőfegyverrel is rendelkeztek, de nem használták, hogy spóroljanak a lőszerrel. Gyermekek és nők is voltak a támadók között, de a gyilkosságokban nem vettek részt. A gyilkosságok hatására a civilek bizalmatlansága a MONUSCO és a FARDC szerveivel szemben tovább nőtt. Számos esetet dokumentáltak, amikor a civilek egy-egy ilyen támadás után segítséget kértek, de a kongói katonák elmulasztották a védelem biztosítását. Ez köszönhető annak, hogy a status quo megszünésével a katonák féltették a fa illegális kitermelésével és eladásával ${ }^{50}$ kapcsolatos üzleti tevékenységüket. ${ }^{51} \mathrm{~A}$ FARDC és az ADF közötti feltételezett üzleti érdek lehetett az egyik oka a felkelésellenes müveletek lelassulásának. Az ENSZ egy jelentésében aggodalmának adott hangot, ugyanis a katonák számos ADF-merénylöt elfogtak, mégis szabadon engedték őket. A vizsgálatok során nem találtak konkrét indokot a szabadon engedésükre, ami a két fél közötti kapcsolatra utal. ${ }^{52}$

A civilek elleni támadások száma 2016-2017 között csökkent, mivel újabb műveleteket hajtottak végre az $\mathrm{ADF}$ ellen. A dezertáltak vallomásai alapján a szervezet ekkor toborzással és szerkezetátalakítással volt elfoglalva. Az ENSZ becslése szerint 2018-ban az összlétszám 400-450 fö között lehetett. ${ }^{53}$ A tagok többsége ugandai volt, de jelentősnek mondható a kongóiak száma, illetve a dezertáltak elmondása alapján tanzániai, burundi és ruandai harcosok is megfordultak a szervezetben. Az ADF egyre nagyobb hangsúlyt fektetett a toborzásra, a gyerekek kiképzésére és felfegyverzésére. ${ }^{54}$

A toborzásnak kétféle módszere volt a leggyakoribb. Az egyik, hogy a mecsetekben különböző hamis ígéretekkel vették rá a potenciális tagokat, hogy hagyják hátra addigi életüket és csatlakozzanak. Adott esetben munkát ígértek nekik, vagy egy harcos vette rá a családja többi tagját a csatlakozásra, és a KDK-ba csempészte őket. Ezenkívül az ADF külön erőfeszítéseket tett annak érdekében, hogy az ugandai dezertáltakat ismét a soraiban tudhassa, ez viszont komoly kockázattal járhat Uganda szempontjából, hiszen tapasztalt harcosok kerülnének ismét az $\mathrm{ADF}$ állományába. ${ }^{55} \mathrm{~A}$ másik módszer a kényszertoborzás, amikor a rajtaütések során embereket raboltak el, akiknek egy részét rabszolgaként kezelték. A szervezet zárt, hierarchikus struktúrájának alján ők helyezkedtek el, akiket embertelen körülmények között tartottak fogva, kényszermunkára ítélve őket, ami legin-

${ }^{50}$ Öt üzletember azt nyilatkozta, hogy 2015-ben fát vásároltak a FARDC tisztjeitől. Az egyik elmagyarázta, hogy havonta két kamionnyi fát vásárolt teherautónként 11100 dollárért a FARDC hadnagyától, beleértve azokat az időszakokat is, amikor a kitermelési terület az ADF ellenőrzése alatt állt. Forrás: United Nations Security Council: Letter dated 16 October 2015... i. m. 18.

51 United Nations Security Council: Letter dated 16 October 2015... i. m. 19-21.

52 United Nations Security Council: Letter dated 23 May 2016 from the Group of Experts on the Democratic Republic of the Congo addressed to the President of the Security Council. 41. [online], 2016. 05. 23. Forrás: undocs.org [2021. 06. 13.]

53 Congo Research Group (2018) i. m. 8.

54 United Nations Security Council: Letter dated 20 May 2018 from the Group of Experts on the Democratic Republic of the Congo addressed to the President of the Security Council. 9. [online], 2018. 06. 04. Forrás: undocs.org [2021. 06. 13.]

55 United Nations Security Council: Letter dated 6 June 2019 from the Group of Experts on the Democratic Republic of the Congo addressed to the President of the Security Council. 9-10. [online], 2019. 06. 07. Forrás: undocs.org [2021. 06. 13.] 
kább a földművelést jelentette. ${ }^{56} \mathrm{Az} \mathrm{ADF}$ a zsákmányszerző hadjáratai során gyerekeket is elrabolt, akiknek a frissen megszerzett áruk - élelmiszer, orvosi eszköz vagy egyéb létfontosságú hiánycikk - szállítása volt a feladatuk. Az elrabolt gyerekek kisebb hányadát a későbbiekben szabadon engedték. A többiek a táborokban háztartási feladatokat láttak el, illetve a földeken dolgoztak. De vannak feljegyzések olyanokról is, akiket kiképeztek arra, hogy a támadásokban vegyenek részt. ${ }^{57}$

Érdemes a nők helyzetéről is beszélni a csoporton belül, amivel képet kaphatunk a szervezeten belüli életről. A társadalom alapvetően patriarchális, és sokan gyakorolják a poligámiát. A nők a táboron belül sokféle feladatot látnak el, lehetnek őrök, szakácsok, tanárok és ápolók. Általában ők látják el a harcból visszatért férfiak sebeit. Viszont anyaként nem érvényesülhetnek, mivel a gyermekeiktől elkülönítve kell élniük, szigorú szabályok szerint, illetve burkát kell viselniük. Ahogy korábban szó volt róla, a nők gyakran elkísérték a harcosokat a rajtaütésekkor, ahol általában fegyvervivők voltak. Ezenfelül információszerző feladatot is betöltöttek, mivel a nők kevésbé vannak kitéve a biztonsági szolgálatok figyelmének. Emellett utánpótlást szereztek vagy adott esetben a toborzásban is segédkeztek. ${ }^{58}$

\section{Az Iszlám Állam Közép-Afrikai Tartománya ${ }^{59}$ - új dimenzió kialakulóban}

Baluku elképzelése, miszerint az ADF-et új szintre kell emelni, egy globális szervezet égisze alatt tűnt a legmegvalósíthatóbbnak, ami jelen esetben az Iszlám Állam lett (ISIS - Islamic State of Iraq and Syria). A két fél közötti kapcsolat komolyságára hívja fel a figyelmet az Amerika Egyesült Államok 2021. márciusi bejelentése, amelynek értelmében az ADFet és vezetőjét a „nemzetközi terrorista” kategóriába sorolta, vagyis ez a státusz megakadályozza a tagok utazását az Egyesült Államokba, befagyasztják az Egyesült Államokkal kapcsolatos eszközöket, megtiltják az amerikaiaknak, hogy üzletet folytassanak velük, és büncselekménnyé teszik a mozgalom támogatását. ${ }^{60}$

Ahhoz, hogy valaki az Iszlám Âllam égisze alá tartozzon, három feltételt kell teljesítenie: az egyik, hogy nyilvánosan elkötelezze magát a kalifának, ami egy hüségesküt jelent. A másik kettő pedig, hogy elfogadja és alkalmazza az ISIS hitvallását és módszertanát. Előbbi az ideológiai és joggyakorlati rendszert jelenti, utóbbi pedig a politikai-katonai stratégiát, módszert tartalmazza. Ezek teljesülése után az adott szervezet vezetője megkapja a tartományi kormányzó címet. Ezenkívül fontos az üzenetek és a cselekvések összehangolása az Iszlám Állammal, mivel utóbbi a propagandatartalmat a globális terjeszkedés egyik eszközeként használja fel. Röviden közvetlen információcserének kell fennállnia. ${ }^{61}$

56 Congo Research Group (2018) i. m. 12-13.

United Nations Joint Human Rights Office (2020) i. m. 12-13.

Congo Research Group (2018) i. m. 12.

Islamic State Central Africa Province - ISCAP.

60 Michelle Nichols: U.S. blacklists groups in Congo, Mozambique over Islamic State links. [online], 2021. 03. 11. Forrás: reuters.com [2021.06. 13.]

61 Candland et al. (2021) i. m. 6-8. 
A pontos dátum, hogy Baluku mikor kezdte el szorgalmazni az ISIS-hez való csatlakozást, nem ismert. Ez nagy valószínüséggel 2016 környékén történhetett meg, amikor a szervezeten belül komoly átalakulás zajlott. Nyilvánvaló, hogy nemcsak az ideológiai kötődés vezérelte Balukut: bízott egy új és stabil utánpótlásvonal kiépítésében. Az Iszlám Állam pénzügyi hálózatába történő integrálódás nagyjából 2017-re tehető, mivel akkor tartózkodott Waleed Ahmed Zein Ugandában, ahol találkozhatott az ADF embereivel, s ezt követően megindulhatott a pénzfolyósítás, elöször kis értékben, később ezres nagyságrendben, dollárban kifejezve. Zeint később az Egyesült Államok leplezte le, de a vizsgálatok a hálózat részleteit illetően még folyamatban vannak. ${ }^{62}$

A közvetett bizonyítékok a két fél kapcsolatára az ADF videóiban lelhetőek fel. 2017-ben számos videót töltöttek fel a közösségi platformokra (Facebook, Telegram, YouTube). ${ }^{63}$ Ez a korábbi visszahúzódóbb felfogáshoz képest nagy váltásnak számított. Korábban is gyártottak tartalmakat, de azok inkább audiofájlok voltak, amelyek az ideológiai tanítást szolgálták. Viszont 2017-től kezdve a katonai képességeit mutatta be a szervezet, egyre több információt adva magáról. Még árulkodóbb a videók minősége. Kezdetben ingyenes videókészítő programokat használt, később viszont egyre kifinomultabb videókészítésről beszélhetünk, ami alapján két lehetőség tünik valószínűnek. Az egyik, hogy az ADF az Iszlám Államnak megküldi a videóit szerkesztésre, vagyis helyben veszi fel, de nem ott vágja össze. A másik elképzelés, hogy az ADF-nek bizonyos szintű médiatartalom-szerkesztési technológiát biztosított az ISIS, amellyel ők maguk végzik el a szükséges szerkesztést. $^{64}$

Fontos kitérni az elnevezésekre. Az ISIS akkori vezetője, Abu Bakr al-Baghdadi 2018 augusztusában az Iszlám Állam Közép-afrikai Tartományának (ISCAP) kialakításán fáradozott. Végül 2019-ben al-Baghdadi egy videóüzenetben hivatalosan is elismerte a térséget az ISIS új tartományaként. ${ }^{65}$ 2016-tól az ADF MTM ${ }^{66}$-ként kezdte beazonosítani magát a videóiban. Ez egy úgynevezett márkaépítési módszer része, amelynek révén szélesebb társadalmi réteget próbált elérni, továbbá már nem (csak) az ugandai sérelmek mentén kívánt tovább szervezkedni. ${ }^{67} \mathrm{~A}$ videók tartalma ezt a fajta irányváltást támasztja alá. Az itt megfogalmazott üzenetekben arra kérik a muszlimokat, hogy csatlakozzanak hozzájuk és harcoljanak a hitetlenek ellen. 2019-töl kezdöden az ISIS egyre több támadást vállalt magára a KDK-ban, amiket az $\mathrm{ADF}$ hajtott végre. Ennek két oka volt. Az egyik jórészt ideológiai, hiszen csak a sikeres, nagy pusztítást okozó támadásokról tudósított, vagyis a hitetlenekkel szembeni eredményes fellépést hangsúlyozza. A másik ok pedig az, hogy 2019 októberében a kongói hadsereg nagyszabású támadást indított, amelynek kimondott célja az ADF megsemmisítése volt, így megemelkedett az összecsapások száma, ami kiváló propagandaalapot biztosított. Ez a civilek életére jelentősen kihatott,

62 Candland et al. (2021) i. m. 18-19.

63 Congo Research Group (2018) i. m. 15.

64 Candland et al. (2021) i. m. 25-26.

${ }_{65}$ Eleanor Beevor - Flore Berger: ISIS militants pose growing threat across Africa. [online], 2020. 06. 02. Forrás: iiss.org [2021. 06. 15.]

66 „Madina at Tauheed Wau Mujahedeen”, ami azt jelenti, hogy „városa az egyistenhitnek, és azoknak, akik ezt megerősítik". Lásd Congo Research Group (2018) i. m. 15.

67 Candland et al. (2021) i. m. 19. 
és a humanitárius szervezetek jelentései szerint csaknem 433 ezer ${ }^{68}$ polgár kényszerült elhagyni lakóhelyét 2019 szeptembere és 2020 március közepe között. A támadásokat az ADF harcosai hajtják végre, és a harcmezőről származó képanyagok néhány nap elteltével már az ISIS központi platformjain jelennek meg, bizonyítva az együttmüködést. Feltételezhetően ennyi időre van szükség a felvételek eljuttatásához és megszerkesztéséhez. ${ }^{69}$ Az Iszlám Állam vezetőjének (Al-Baghdadi) 2019. októberi halála után kérdésessé vált a tartományok jövője, de Baluku 2020 júniusában továbbra is a hűségét és elkötelezettségét hangoztatta. Az ADF 2020 szeptemberében egy saját közösségi platformot hozott létre Mujahideen TV címmel, amely tartalmazza az ISCAP logóját is. A helyi média célja továbbra is a toborzás elősegítése, illetve jelentős morálerősitő funkciót is ellát, amikor az elesett harcostársakat dicső́ti, illetve bemutatja a támadások sikerét. ${ }^{70}$

Meg kell említeni az ADF transznacionális hálózatát, amelynek a legfontosabb térsége Kelet-Afrika. Korábban kenyai és a tanzániai Tangában található sejtek jelentős támogatást nyújtottak Mukulunak, de nagy valószínűséggel a letartóztatás után is tovább működik az anyagi támogatás folyósítása. Toborzás terén pedig Tanzánia, Burundi és Mozambik játszanak egyre hangsúlyosabb szerepet. Emellett a londoni támogatási hálózat sem elhanyagolható, amely az Iszlám Állammal való kapcsolat miatt még jövedelmezőbb lehet. ${ }^{71}$ Végül ki kell emelni az ISCAP-ot, amivel kapcsolatban egyre biztosabban lehet azt állítani, hogy több komponensből áll, nem csak az ADF-ből, hanem a Mozambik északi részén, Cabo Delgadóban tevékenykedő Ansar al-Sunnából is. Ezt erősítette meg 2021 márciusában az Egyesült Államok Külügyminisztériuma azzal, hogy e két szervezetet egyszerre nyilvánította terrorcsoportnak az ISCAP-ban való egyesülésük miatt. ${ }^{72} \mathrm{Az}$ Iszlám Állam, valamint annak kongói és mozambiki ágai közötti kapcsolat mértéke még mindig nem világos, föleg a képzés, kiképzés terén. E csoportok elismerése megerősítheti az ISIS globális terjeszkedését, jelenlétét és erejét, annak ellenére, hogy a Közel-Keleten drasztikusan visszaesett. $^{73}$

\section{Összegzés és konklúzió}

Az elemzés a kezdeti időszakot érintően az ADF-NALU létrejöttének körülményeit vázolta fel, szemléltetve, hogy Szudán és Kongó Kampalával szembeni hatalmi játszmájának köszönhető a megerősödésük. A 2000-es évek derekán a szervezetnek önfenntartóvá kellett válnia, ami a terület alapos kiismerésével és a lakossággal való szimbiózis elérésével valósult meg. Ekkorra kialakult az általános védekező taktikájuk a folyamatos támadásokkal szemben. Amikor offenzívát indított a FARDC, akkor visszavonultak, magára hagyva

68 United Nations Joint Human Rights Office (2020) i. m. 15

69 Candland et al. (2021) i. m. 20-24.

70 Candland et al. (2021) i. m. 32-34.

71 Candland et al. (2021) i. m. 38-40.

72 U.S. Department of State: State Department Terrorist Designations of ISIS Affiliates and Leaders in the Democratic Republic of the Congo and Mozambique. [online], 2020. 03. 10. Forrás: state.gov [2021. 06. 20.]

73 Amanda M. Makosso - Auréole Collinet: Islamic State Central Africa Province (ISCAP): A threat to regional stability and security. The Journal of Intelligence, Conflict, and Warfare, 4. (2021), 1. 5. [online], 2021. 05. 31. Forrás: sfu.ca [2021. 09. 30.] 
a helyi lakosságot, amikor pedig a reguláris haderők kivonultak, a harcosok visszaáramlottak.

Egy folyamatosan mozgásban lévő szervezetről van szó, amelyben belső válságok is kibontakoztak. A NALU kiválásával már egy iszlamista csoportról beszélünk, majd Mukulu letartóztatásával és Baluku hatalomra jutásával a mozgalom egy olyan takfirista, ${ }^{74}$ szélsőséges álláspontot kezdett el képviselni, amely egy platformra hozta a többi szunnita dzsihádi mozgalommal. ${ }^{75}$ Baluku vezetésével a civilek elleni támadások megszaporodtak, aláásva ezzel a kelet-kongói lakosság biztonsági erőkbe vetett bizalmát és hitét. Végül pedig a globális színtérre való kilépés következett, legalábbis a hálózatépítésben, amelyet az ADF az Iszlám Állam segítségével tervez megvalósítani. Ez a kapcsolat kölcsönösen előnyös mindkét fél számára. Az ISIS az itt készített anyagokat fel tudja használni a globális terjeszkedéséhez, az összefogás elösegítéséhez, míg az ADF-nek a propaganda müködtetéséhez nyújt segítséget.

Földrajzi működése ellenére az ADF továbbra is egy ugandai szervezet, hisz a vezetés döntő többsége továbbra is onnan származik. Mégis, a központoktól távol eső vidéken, egy másik országban viszonylag nagy szervezetté tudott válni. Egyetértek a Congo Research Group állításával, amely szerint a térség országainak először a muszlim fiatalok radikalizálódását kell megállítaniuk, hiszen a szervezet ezt használja ki. ${ }^{76} \mathrm{Az}$ elmúlt 25 év rávilágított arra, hogy egy határvidéken berendezkedő mozgalom felszámolásához a felkelésellenes müvelet indítása kevés, vagyis a katonai megoldás önmagában nem elegendő. Átfogó gazdasági és szociális intézkedések kellenek, hogy a fiatalok és az elégedetlen lakosság számára más alternatívák is elérhetők legyenek, mint a dzsihádistáké. A szervezet toborzó tevékenysége egyre sikeresebb, és az ISCAP révén az ADF kapcsolati hálója egyre jobban kiterjedhet. Így a bevezetőben kiemelt alkalmazkodó és megújuló képességgel kombinálva a mozgalom a jövőben még ellenállóbbá és erősebbé válhat, egyre komolyabb fenyegetést jelentve Uganda és a Kongói Demokratikus Köztársaság számára.

\section{Felhasznált irodalom}

Beevor, Eleanor - Flore Berger: ISIS militants pose growing threat across Africa. [online], 2020. 06. 02. Forrás: iiss.org [2021. 06. 15.]

Besenyő János - Gyarmati Ádám - Hetényi Soma Ambrus - Pető Gergő - Szijj Dóra - Resperger István: Országismertető - Kongói Demokratikus Köztársaság. Székesfehérvár, MH Összhaderőnemi Parancsnokság Tudományos Tanácsa, 2011.

Candland, Tara - Adam Finck - Haroro J. Ingram - Laren Poole - Lorenzo Vidino - Caleb Weiss: The Islamic State In Congo. [online], 2021. 03. Forrás: gwu.edu [2021. 06. 12.]

Congo Research Group: Inside the ADF Rebellion - A Glimpse into the Life and Operations of a Secretive Jihadi Armed Group. [online], 2018. 11. Forrás: congoresearchgroup.org [2021. 06. 14.]

Democratic Republic of the Congo. [online], 2021. 06. 14. Forrás: cia.gov [2020. 06. 15.]

Hansen, Stig Jarle: Horn, Sahel and rift. Fault-lines of the African jihad. London, Hurst, 2019.

\footnotetext{
${ }^{7}$ Kiközösítés vagy az iszlám hit elleni hitehagyás kijelentése, amit a többi muszlim ellen elkövetett szélsőséges erőszak igazolására használnak.

75 Candland et al. (2021) i. m. 8.

76 Congo Research Group (2018) i. m. 20.
} 
Hansen, Stig Jarle: Tracking the DRC's Allied Democratic Forces and its links to ISIS. [online], 2019. 05. 08. Forrás: theconversation.com [2021.06. 12.]

International Crisis Group: Eastern Congo: The ADF-NALU's Lost Rebellion. [online], 2012. 12. 19. Forrás: crisisgroup.org [2021. 06. 12.]

Makosso, Amanda M. - Auréole Collinet: Islamic State Central Africa Province (ISCAP): A threat to regional stability and security. The Journal of Intelligence, Conflict, and Warfare, 4. (2021), 1. [online], 2021. 05. 31. Forrás: sfu.ca [2021. 09. 30.] Online: https://doi.org/10.21810/jicw.v4i1.2825

NATO: NATO Standard, Allied Joint Doctrine For Counter-Insurgency (COIN). [online], 2016. 07. Forrás: publishing.service.gov.uk [2021.09.30.]

Nichols, Michelle: U.S. blacklists groups in Congo, Mozambique over Islamic State links. [online], 2021. 03. 11. Forrás: reuters.com [2021. 06. 13.]

No celebrations as Rwenzururu kingdom marks 11 years. [online], 2020. 10. 20. Forrás: independent.co.ug [2021. 06. 14.]

Rwenzururu Kingdom. [online], 2021. 06. 14. Forrás: fortuneofafrica.com [2021. 06. 14.]

Scorgie, Lindsay: Peripheral Pariah or Regional Rebel? The Allied Democratic Forces in the Uganda / Congo Borderland. The Commonwealth Journal of International Affairs, 100. (2011), 412. [online], 2011. 02. 18. Forrás: static1.squarespace.com [2021. 06. 17.] Online: https://doi.org/10.1080/00358533.2011.542297

T. Horváth Attila: Az ADF-NALU - Egy nagy múltú gerillaszervezet a Kongói Demokratikus Köztársaságban. In Afrikai terrorista- és szakadárszervezetek. Budapest, 2015. 439-455.

Titeca, Kristof - Daniel Fahey: The many faces of a rebel group. The Allied Democratic Forces in the Democratic Republic of Congo. [online] 2016. 09. Forrás: researchgate.net [2021. 06. 15.] Online: https://doi. org/10.1111/1468-2346.12703

Titeca, Kristof - Kloen Vlassenroot: Rebels without borders in the Rwenzori borderland? A biography of the Allied Democratic Forces. Journal of Eastern Africa Studies, 6. (2012), 1. Online: https://doi.org/10.1080 /17531055.2012.664708

United Nations Joint Human Rights Office: Report on violations of human rights and international humanitarian law by the Allied Democratic Forces armed group and by members of the defense and security forces in Beni territory, North Kivu province and Irumu and Mambasa territories, Ituri province, between 1 January 2019 and 31 January 2020. [online], 2020. 07. Forrás: ohchr.org [2021. 06. 13.]

United Nations Security Council: Letter dated 6 June 2019 from the Group of Experts on the Democratic Republic of the Congo addressed to the President of the Security Council. [online], 2019. 06. 07. Forrás: undocs.org [2021. 06. 13.]

United Nations Security Council: Letter dated 12 January 2015 from the Chair of the Security Council Committee established pursuant to resolution 1533 (2004) concerning the Democratic Republic of the Congo addressed to the President of the Security Council. [online], 2015. 01. 12. Forrás: undocs.org [2021. 06. 13.]

United Nations Security Council: Letter dated 16 October 2015 from the Group of Experts extended pursuant to Security Council resolution 2198 (2015) addressed to the President of the Security Council. [online], 2015. 11. 16. Forrás: undocs.org [2021. 06. 13.]

United Nations Security Council: Letter dated 19 June 2014 from the Chair of the Security Council Committee established pursuant to resolution 1533 (2004) concerning the Democratic Republic of the Congo addressed to the President of the Security Council. [online], 2014. 06. 25. Forrás: undocs.org [2021. 06. 13.]

United Nations Security Council: Letter dated 20 May 2018 from the Group of Experts on the Democratic Republic of the Congo addressed to the President of the Security Council. [online], 2018. 06. 04. Forrás: undocs.org [2021. 06. 13.]

United Nations Security Council: Letter dated 23 May 2016 from the Group of Experts on the Democratic Republic of the Congo addressed to the President of the Security Council. [online], 2016. 05. 23. Forrás: undocs.org [2021. 06. 13.]

U.S. Department of State: State Department Terrorist Designations of ISIS Affiliates and Leaders in the Democratic Republic of the Congo and Mozambique. [online], 2020. 03. 10. Forrás: state.gov [2021. 06. 20.]

View Red Notices. [online], 2021. 06. 16. Forrás: interpol.int [2021. 06. 16.] 